\title{
Evaluation of English Learning in Junior High School Samaturu Kolaka
}

\author{
Suardi \\ Lecturer, Gunadarma University, Indonesia
}

\begin{abstract}
The study aims to evaluate of English learning at the Junior High School 3, Samaturu Kolaka. The method used is evaluative through the flow of the gap model (discrepancy evaluation model). Data collection through interviews, document tracing, and observation. Key Informant is the principal, teacher, and student. The results showed that: (1). The ten indicators of the principles in the preparation of lesson plan is only a contemporary-oriented indicator that is not contained in the lesson plan. This is because lesson plan is based on teaching materials and teaching materials. In addition, the lesson plan does not promote social, spiritual attitudes and only focus on English language teaching materials. Because of social and spiritual attitudes are hidden curriculum and can be applied to all subjects. Even the development of character is a program of Junior High School 3, Samaturu Kolaka. (2). All step-by-step indicators in lesson plan preparation are already loaded inside the lesson plan. But there is still an unprecedented indicator such as determining a monotonous learning strategy and not self-evaluation for the teacher to improve the strategy, and its teaching method. (3). Several indicators of lesson plan implementation have been carried out well in the classroom even though it is not maximized. This is due to preliminary activities, the teacher does not explain the importance of the material to be studied and competencies that students must master. The conclusion is related to the principles, application of steps and implementation of lesson plan in the classroom, although not maximized, but has been referring to Permendikbud no. 103 year 2014 about learning on primary education and secondary education.
\end{abstract}

Keywords: English Learning, Evaluation, Lesson Plan

\section{Introduction}

The English teachers at Junior High School 3 Samaturu Kolaka hopes for success in his assignment as an English teacher who can make his students succeed in learning English. Students can use English well in communicating both verbally and in writing. Learning tools are very important for a teacher, because they affect the preparation, process and evaluation of learning. The device must be arranged based on needs and refer to the syllabus or curriculum that applies.

The reason the researcher conducted an evaluation of English learning at Junior High School 3 Samaturu Kolaka was the initial activity in conducting learning activities, the success of a learning was determined by the quality of the plans made. This has made the preparation of lesson plans important for teachers. To implement English learning as outlined in the syllabus, the teacher must prepare a lesson plan. Lesson plan is a guide for teachers in implementing learning both in class, laboratory, and/field for each basic competency. Therefore, what is stated in the lesson plan contains matters that are directly related to learning activities in an effort to achieve mastery of a basic competency.

Based on the results of preliminary observations found several problems including; some English teachers at Junior High School 3 Samaturu Kolaka have not optimally developed a lesson plan. Some teachers are only able to make lesson plans in groups so that lesson plans are not based on the needs of students in the class, while each student has their own character. The ideal lesson plans are lesson plans that are arranged and developed based on the needs and character of students in the classroom. In addition, there are also some teachers who only copy and paste lesson plans have other English teachers. So that the lesson plan does not fit the needs of students. 
Developing a lesson plan is only considered as a formality and administrative activity so that it is not made based on the steps in the preparation of the lesson plan and does not apply the principles in the preparation of the lesson plan. Furthermore, lesson plans that have been prepared are not applied in the classroom and lesson plans are not used as a reference in developing learning materials in the classroom. All this time, learning English in schools takes precedence over improving the results of the national exam scores, compared to the communicative abilities of students who on average are still low.

The ability of students to use communicative English is cause for concern because the average teacher focuses more on teaching grammar, learning listening and reading skills as demanded on national examinations. Speaking and writing skills are often ignored. Therefore, students' competence in speaking skills is still low, due to difficulties with pronunciation or pronunciation. Likewise, difficulty in reading or comprehending reading texts due to lack of knowledge of reading material and vocabulary and ignorance connecting ideas in sentences. Likewise, with writing skills that are difficult because they require systematic and complex thinking.

With some of the problems above, researchers intend to conduct research on the evaluation of English learning in Junior High School 3 Samaturu Kolaka using the discrepancy evaluation model.

\section{Literature Review \\ Learning Evaluation}

Learning evaluation is collecting the right data so that it can be continued by giving the right guidance as well. Evaluation of learning is very useful especially for decision makers, with input from the evaluation of learning that decision makers will determine the follow-up of learning that is being or has been implemented. The realization of the results of the evaluation of learning is a recommendation from the evaluator for decision makers.

According to Carpenter et. al., (2018) defining evaluation of learning is an effort in conducting analysis, collecting data in the field, and looking for various information in the field. McDavid, Huse and Hawthorn (2017) said that there are several parts to the evaluation of learning including: validity, reliability, meaningfulness and understandability, balance and completeness, timeliness and ability to act, degree of goal displacement, and practical considerations. According to Froncek (2018) that learning evaluation consists of gathering information about learning activities, characteristics, and learning outcomes to make an assessment that aims to improve or develop learning, and increase understanding or inform decision making about learning that has been implemented.

Goodier et. al., (2017) that the evaluation of learning is done to see the level of efficiency, implementation, results and costs of a learning. In line with this understanding, Topper and Lancaster (2016) states the evaluation of learning is needed to test the evaluation model or approach to determine the most appropriate planning model to be applied.

The reasons for the importance of learning are evaluated, stated by Noe (2010) as follows: (a) to identify the strengths and weaknesses of learning; (b) assess whether the content, organization, and administration of learning contribute to training learning; (c) to find out the level of satisfaction with training learning; (d) to determine financial benefits and learning costs; (e) to compare the costs and benefits of learning investments; and (f) comparing the costs and benefits of different learning to choose the best learning

According to Benny (2014) that the evaluation carried out on the implementation of a learning basically aims to: (a) find out the effectiveness and efficiency of training learning; (b) obtain information about whether the organization of learning is accepted by participants; (c) improve the quality of learning organization; (d) decide on the sustainability of the learning process; and (e) know the impact of organizing learning.

\section{Discrepancy Evaluation Model}

There are various models of evaluation research proposed by evaluation research experts. The experts compile evaluation models that are used as a guide for evaluating learning systematically, and each model has a different approach. However, despite differences in approach, none of the models is the best among the models because each model has its own advantages and disadvantages. 
Based on the opinions expressed by Royse, Thyer and Padgett (2010) that learning evaluation activities involve a comparison process, and cannot be said to be a form of evaluation without a form of comparison. Meanwhile according to Provus (1969) which revealed that there were no evaluation activities without information gaps.

The selection of evaluation models used in this research activity is determined based on the focus, objectives, and evaluation questions developed. Based on the problem formulation that has been formulated above, the evaluation model used in this study is the Discrepancy Evaluation Model. This model is very suitable to be used to determine the effectiveness of learning by exploring the gaps that occur in the display of the implementation of learning in the field.

The steps taken in the gap evaluation model include the process of (a) agreeing to standards, (b) determining whether there is a gap between the display of learning and the established learning implementation standards, (c) using information gap to determine attitudes whether improving, improving or stop learning or just a few aspects. Digging the gaps in the display of the implementation of learning in the field will go through a comparison step with predetermined learning standards/criteria.

The gap evaluation model is intended to obtain information on gaps that occur with a view to knowing the effectiveness of the learning display in the field that is useful for decision making.

\section{a. Unit I: Program Design}

Program design is a decision making on the description of learning design. In other words, the learning design unit is the formulation of learning evaluation criteria which is used as the standard for evaluating implementation. The purpose of the learning design unit in this study is to analyze the application of the principles of the preparation of learning implementation lesson plan at Junior High School 3 Samaturu Kolaka.

\section{b. Unit II: Program Operation}

In the program operations evaluation unit, the standard used to compare is the learning design obtained from the learning design unit. The purpose of evaluating the operation of learning in this study is to analyze the application of the steps in the preparation of lesson plan in English at Junior High School 3 Samaturu Kolaka.

\section{c. Unit III: Interim Products Program}

Evaluation of the interim results of learning is the collection of data on the implementation of learning to determine whether it has worked and succeeded as expected. The assessment is carried out on fulfilling the objectives of analyzing the lesson plan of English learning at Junior High School 3 Samaturu Kolaka.

\section{d. Unit IV: Program Product}

Evaluation of the program product is the determination of whether the learning objectives are achieved. Evaluation of the final outcome of learning aims to make a follow-up study based on achieving the ultimate goal of the overall evaluation of learning.

In the study conducted only used three units, namely the program design unit, program operation unit, program product unit. This was done because the researcher did not study the whole, but only focused on the lesson plan.

\section{Lesson Plan}

According to Permendikbud Number 103 of 2014 that the plan for implementing learning, here in after referred to as lesson plan, is a learning plan developed that refers to the syllabus. The lesson plan is translated from the syllabus to direct student learning activities in an effort to achieve basic competencies.

Every teacher in the education unit is obliged to prepare lesson plans in a complete and systematic manner so that learning takes place interactively, inspiratively, fun, challenging, motivating students to participate actively, as well as providing sufficient space for initiative, creativity, and independence in accordance with their talents, interests, and development physically and psychologically students. The lesson plans are prepared for each basic competency that can be carried out in one or more meetings. The teacher designs lesson plans for each meeting tailored to the scheduling of the educational unit. 
In the implementation it is not so the same as what was planned, because the learning process itself is situational. However, if the plan has been prepared carefully, then the process and the results will not be too far from what was planned. The term learning planning currently used is related to the implementation of the 2013 curriculum in schools in Indonesia, namely the lesson plan, which is then known as the term unit lessons, lesson plans, and other similar terms.

The following explanation regarding Permendikbud Number 103 of 2014 above is; subject identity, including: education unit, class, semester, learning expertise, subject or theme, number of meetings. Competency standard is a minimum ability qualification of students that describes the mastery of knowledge, attitudes, and skills that are expected to be achieved in each class and semester in a subject.

Basic competence is a number of abilities that students must master in certain subjects as a reference for the preparation of competency indicators in a lesson. Competency indicators are behaviors that can be measured or observed to show the achievement of certain basic competencies that are subject to assessment of subjects. Indicators of competency achievement are formulated using operational verbs that can be observed and measured, which include knowledge, attitudes, and skills.

Learning objectives describe the process and learning outcomes that are expected to be achieved by students in accordance with basic competencies. Teaching material contains facts, concepts, principles, procedures that are relevant, and written in the form of items in accordance with the formulation of indicators of competency achievement. The time allocation is determined according to the need to achieve basic competencies and learning load. The learning method is used by teachers to create a learning atmosphere and learning process so that students achieve basic competencies or a set of predetermined indicators.

The selection of learning methods is adjusted to the situation and condition of the students, as well as the characteristics of each indicator and the competencies to be achieved in each subject. The procedures and instruments for evaluating the process and learning outcomes are adjusted to the indicators of competency achievement and refer to the assessment standards. Determination of learning resources is based on competency standards and basic competencies, teaching materials, learning activities, and indicators of competency achievement.

Related to implementation, the lesson plan in class is a very difficult thing to do by the teacher because sometimes when learning suddenly does not match the learning plan and deviates. This happens because there are things that are not appropriate and the learning plan is not enough to help produce good learning so that the teacher improvises in learning. Therefore, teachers must immediately make adjustments and make variations of learning by giving individual assignments, working in pairs, group work and organizing learning time.

\section{English Learning}

The word learning emphasizes more seriously student learning activities that involve intellectual, emotional, and social aspects. In the broad sense of learning is a process or activity that is systematic and systemic, which is interactive and communicative between educators and students, learning resources and the environment to create a condition that allows the occurrence of student learning actions, both in the classroom and outside the classroom, attended by the teacher physical or not to master the competencies that have been determined.

According to Brown (2000) that learning is the acquisition or acquisition of knowledge about a subject or a skill by learning, experience or instruction. Learning is an activity carried out by instructional teachers who create a process of interaction between fellow students, the teacher with students and with learning resources.

The learning process is carried out interactively between the teacher and students, where both parties play an active role and act within a framework and framework of thinking that is mutually agreed upon. The linkage of student activities to the activities of teachers in teaching and learning activities is the relationship between stimulus and response. According to research results Hwang and Wang (2016) it is said that the purpose of learning is to develop students' abilities, be able to apply their knowledge in the context of everyday life, and learning becomes an important way to enable students to experience what they will encounter in everyday life. 
According to Chik and Ho (2017) It is said that language learning can be done outside the classroom to supplement learning weaknesses in the classroom. Learning is related to curriculum objectives and plans, which focus on methodological issues, such as teaching techniques, resource implementation activities, and measurement tools used in specific learning situations. Learning objectives, learning materials, teachers and students, types of activities carried out, facilities / infrastructure available, and assessments. These components are interdependent, interrelated, and influence each other within the framework of the learning process and function in an integrated manner towards the learning objectives.

The learning process is experienced throughout a human's life and can apply wherever and whenever. Learning has a meaning similar to teaching, although it has a different connotation. In the context of education, the teacher teaches so students can learn and master the content of the lesson to achieve something determined objectives.

Learning objectives are a predetermined formulation of behavior to suit students as a result of the learning actions that have been done. Clear objectives will provide clear guidance on the selection of teaching materials, strategies, media and evaluation. In the process of learning objectives can be broken down into goals that are cognitive (knowledge), affective (attitude), psychomotor (skills). The degree of attainment of this goal is an indicator of the quality of achievement of goals and the results of student learning. Objectives are the main focus of teaching and learning activities.

\section{Research Method}

The research method used is evaluative research method. Evaluative research intends to collect data on policy implementation. One function of evaluation is as a form of developing a system that has various components. As an evaluative study, the approach used is a qualitative approach with an evaluation method of English learning referring to the discrepancy evaluation model developed by Provus (1969). The discrepancy evaluation model consists of three evaluation components including; (1) program design (application of the principles of preparation of lesson plans), (2) program operational (application of steps in the preparation of lesson plans), and (3) program product (implementation of lesson plans). This research was conducted at Junior High School 3 Samaturu Kolaka. Data collection was carried out in this study through interviews, documentation, and observation. Key informants are principals, teachers and students.

\section{Results and Discussion}

The results obtained after analyzing the discrepancy evaluation model are used as a basis for answering the problem formulation. Explanation of the answer can be described as follows:

\section{Application of the Principles of Lesson Plan English}

Indicators of the principles of lesson plan are (1) contain in full the basic competencies of spiritual attitudes, social attitudes, knowledge, and skills; (2) can be held in one or more meetings; (3) pay attention to individual student differences; (4) student centered; (5) context based; (6) present oriented; (7) developing learning independence; (8) provides feedback and follow up on learning; (9) having interconnectedness and intercompetence; and (10) utilizing information and communication technology. Of the ten indicators, only present-oriented indicators are not included in the lesson plan.

This is because the lesson plans are arranged based on teaching materials and teaching materials. In addition, the lesson plan does not prioritize social, spiritual attitudes and only focus on English teaching materials. Because social and spiritual attitudes are hidden curriculum and can be applied to all subjects. In fact, character development is a lesson plan at Junior High School 3 Samaturu Kolaka.

The learning process that makes the surrounding environment a source of learning. The learning environment is all things that can be heard and seen that also influence the process of language communication. To be more clear, including the language environment is like a situation in the classroom when the learning process takes place, in markets, shopping centers, restaurants, conversations with groups of people, while watching television, when reading the mass media or various other reading materials and other environmental situations. So that the language environment is not limited to conditions, time and environment. 
This is consistent with the results of research conducted by Scrimin et. al., (2018) that students can learn independently, have motivation if supported by learning objectives, implement effective learning strategies, monitor student progress, apply environmental conditions that are conducive for learners. A learning process is inseparable from teaching and learning activities. Likewise according to Jakonen (2017) which says that the material environment of language in the classroom does not only function as an increase in human resources. However, as a target to achieve learning objectives and can facilitate language growth. Therefore, a good language environment is an environment that can provide the widest opportunity for students to get a new language learned.

According to Dallinger et. al., (2016) also explained that based on several studies both theoretically and practically it is said that the success of learning is influenced by student characteristics, student achievement, cognitive abilities, motivation, or demographic factors, followed by class factors, namely instructional quality or class composition.

Based on the explanation above, it can be concluded that the aspects of learning design related to the principles of the preparation of the lesson plan are in accordance with Permendikbud Number 103 of 2014 on Basic Education and Secondary Education.

\section{Steps Lesson Plan}

Indicators of the steps in the preparation of lesson plan namely (1) syllabus study; (2) formulation of achievement indicators for core competencies KI-1, KI-2, KI-3, and KI-4; (3) learning material; (4) description of learning activities; (5) determination of time allocation; (6) development of learning assessment; (7) determining learning strategies; (8) determine the media, tools, materials and learning resources. In general, all indicators of the steps in the preparation of the lesson plan have been contained in the lesson plan. But there are indicators that have not been maximized such as determining learning strategies that seem monotonous and do not conduct self-evaluations for teachers to improve their strategies, and teaching methods.

In accordance with the needs of the relevant education unit level so that one of the steps is to refer to the syllabus. According to Dvorghets and Shaturnaya (2015) that a good syllabus module is a syllabus that contains media, genre, context, case studies, practice, analysis, evaluation, and explanation. The syllabus serves as a reference in the preparation of the lesson plan, meaning that the syllabus as a learning process plan is not final, it must be followed up with a lesson plan, so that it is focused and concrete.

According to Rajaee and Abdolahzadeh (2013) that the syllabus is a specification of the content of language teaching so that the learning process is more effective in achieving learning objectives. The description of learning activities in the syllabus in a more operational form in the form of a scientific approach is adjusted to the conditions of students and educational units including the use of media, tools, materials, and learning resources. Determination of time allocation for each meeting based on time allocation in the syllabus, then divided into preliminary, core, and closing activities.

In line with the above opinion, Lunina and Minaeva (2015) in the results of his research also explained that in addition to the syllabus, the material is also important, learning material can be made from various video sources so that it offers a variety of English topics that depend on the needs of students.

Based on the explanation above, it can be concluded that the aspects of learning operations related to the steps in preparing the lesson plan are in accordance with Permendikbud Number 103 of 2014 on Basic Education and Secondary Education.

\section{Implementation of Lesson Plan English}

Indicators of implementing the lesson plan are; (1) preliminary activities; (2) core activities; (3) the closing activities have been carried out well in the classroom even though they have not been maximized. This is because there are still some shortcomings such as preliminary activities that do not explain the importance of the material to be learned along with the competencies that students must master, and when closing activities the teacher does not summarize the teaching material that has been learned. 
Furthermore, according to Chik and Ho (2017) it is said that language learning can be done outside the classroom to supplement learning weaknesses in the classroom. In the closing activity aspect it was found that the teacher did not make a summary/conclusion of the lesson even though the summary of the lesson was important for students to understand the overall teaching material provided by the teacher through the summary of teaching material.

Based on the explanation above, it can be concluded that the aspects of the learning outcomes related to the implementation of the lesson plan are in accordance with Permendikbud Number 103 of 2014 on Basic Education and Secondary Education.

\section{Conclusion}

Based on the results of the above research, it can be concluded that the principles, implementation of the steps and implementation of the lesson plan, although not yet optimal, have already referred to Permendikbud Number 103 of 2014 on Basic Education and Secondary Education. This can be seen below:

1. The ten indicators of the principles in the preparation of lesson plan is only a contemporary-oriented indicator that is not contained in the lesson plan. This is because lesson plan is based on teaching materials and teaching materials. In addition, the lesson plan does not promote social, spiritual attitudes and only focus on English language teaching materials. Because of social and spiritual attitudes are hidden curriculum and can be applied to all subjects. Even the development of character is a program of Junior High School 3, Samaturu Kolaka.

2. All step-by-step indicators in lesson plan preparation are already loaded inside the lesson plan. But there is still an unprecedented indicator such as determining a monotonous learning strategy and not self-evaluation for the teacher to improve the strategy, and its teaching method.

3. Several indicators of lesson plan implementation have been carried out well in the classroom even though it is not maximized. This is due to preliminary activities, the teacher does not explain the importance of the material to be studied and competencies that students must master.

\section{Recommendation}

The recommendations submitted based on the results of the evaluation carried out are;

1. Teachers are expected to develop lesson plan to meet the specific needs of the students.

2. Expected operation of English learning implementation program in Junior High School 3, Samaturu Kolaka, teachers need to conduct self-evaluation to improve the strategy, and teaching method.

3. Teachers are expected to explain the importance of the material to be learned following competencies that students must master, and when the teacher's closing activities do not summarize the teaching materials that have been studied.

\section{Reference}

[1] Carpenter, Dale, R. Corbin, \& N. Luke. (2018). Assessment of Operational Effectiveness for Education Program Providers. International Journal of Assessment and Institutional Effectiveness.

[2] McDavid, James, I. Huse, \& L. Hawthorn. (2017). Program Evaluation and Performance Measurement and Introduction to Practice, $2^{\text {nd }}$ Edition. New York: Sage Publication Inc.

[3] Froncek, Benjamin. (2018). Evaluator Competencies in the Context of Diversity Training: The Practitioners' Point of View. International Journal Evaluation and Program Planning.

[4] Goodier, Sarah, C. Field, S. Goodman. (2017). The Need for Theory Evaluation in Global Citizenship Programmes: The Case of the Gcsa Programme. International Journal Evaluation and Program Planning.

[5] Topper, Andrew, \& S. Lancaster. (2016). Online Graduate Educational Technology Program: An Illuminative Evaluation. International Journal Studies in Educational Evaluation.

[6] Noe, Raymond A. (2010). Employee Training and Development, $5^{\text {th }}$ Edition. Boston: Mc-Graw Hill.

[7] Pribadi, Benny A. (2014). Desain dan Pengembangan Program Pelatihan Berbasis Kompetensi: Implementasi Model ADDIE. Jakarta: Prenada Media Group. 
[8] Royse, David, A. Thyer, K. Padgett. (2010). Program Evaluation: An Introduction, $5^{\text {th }}$ Edition. New York: Cengange Learning.

[9] Provus, Malcolm M. (1969). The Discrepancy Evaluation Model: An Approach to Local Improvement and Development. Pennsylvania: U.S. Departement or Health, Education \& Welfare Office of Education.

[10] Permendikbud Nomor 103 tahun 2014 tentang Pembelajaran Pada Pendidikan Dasar dan Pendidikan Menengah. Pasal 1 ayat 2.

[11] Brown, H. Douglas. (2000). Principles of Language Learning and Teaching. New York: Pearson Education.

[12] Hwang, Gwo-Jen \& S. Yi Wang. (2016). Single Loop or Double Loop Learning: English Vocabulary Learning Performance and Behavior of Students in Situated Computer Games With Different Guiding Strategies. International Journal Computers \& Education.

[13] Chik, Alice \& J. Ho. (2017). Learn a Language for Free: Recreational Learning Among Adults. International Journal System.

[14] Scrimin, Sara, E. Patron, E. Ruli, C. Pagui. (2018). Dynamic Psychophysiological Correlates of a Learning from Text Episode in Relation to Reading Goals. International Journal Learning and Instruction.

[15] Jakonen, Teppo. (2017). The environment of a Bilingual Classroom as an Interactional Resource. International Journal Linguistics and Education.

[16] Dallinger, Sara, K. Jonkmann, J. Hollma, C. Fiege. (2016). The Effect of Content and Language Integrated Learning on Students' English and History Competences Killing Two Birds with One Stone?. International Journal Learning and Instruction.

[17] Dvorghets, Olga S. \& A. Shaturnaya. (2015). Developing Students' Media Literacy in the English Language Teaching Context. International Journal Procedia-Social and Behavioral Sciences.

[18] Nia, Rajaee, Mahdi, \& E. Abdolahzadeh. (2013). A Critical Review of Recent Trends in Second Language Syllabus Design and Curriculum Development. International Journal of Research Studies in Language Learning.

[19] Lunina, Mikhail \& L. Minaeva. (2015). Translated Subtitles Language Learning Method: A new Practical Approach to Teaching English. International Journal Procedia-Social and Behavioral Sciences. 